\title{
THE ECONOMIC IMPACT OF NPKMg FERTILIZERS ON \\ SMALL HOLDER COCONUTS \\ (A Case Study in Indonesia)
}

\author{
S. Asnawi and S.N. Darwis ${ }^{1)}$
}

\section{INTRODUCTION}

Before 1939, Indonesia was the largest copra exporter in the world (FAO 1983). But since then until 1970 it was only the second largest copra exporter after the Philippines (Heesch \& Kuhlmann 1982). Between 1970 and 1980 the exports of copra from Indonesia declined drastically from 184,000 tons in 1970 to only 36,000 tons in 1980 , on average a decrease of about 37.6 per cent per annum for the period (Asnawi \& Darwis 1984). Since 1983 Indonesia has had to stop exports of copra due to a deficit in national coconut production relative to domestic needs. For example, in 1983 the total production of coconut in Indonesia was only about 2.4 million tons copra equivalent while the total consumption of coconut in the country in that year was about 2.48 million tons. Thus, there was a deficit in coconut production of about 80,000 tons copra equivalent in the country in that year (Asnawi \& Darwis 1984).

The deficit was particularly due to the fact that since 1970, the average growth rate of the coconut production has only been 3.9 per cent per annum while the average growth rate of coconut consumption has been 5.8 per cent per annum. The lower growth rate of production was primarily due to continued lack of management (e.g. no chemical fertilizers applied), so that the fruit yields of coconut palms in Indonesia remained at the low level of about $800 \mathrm{~kg}$ copra/ha/year (Davis 1983). The higher growth rate of consumption was not merely due to the population growth (2.3 per cent per year) but also because of the increase in per capita income of Indonesians (3.6 per cent per year) as a result of the rising economic development of the country (FAO 1983).

One of the fastest and the cheapest ways to increase coconut production is through coconut intensification programs, particularly by applying appropriate chemical fertilizers. With chemical fertilizers, the productivity of existing coconut palms can be increased in a relatively short time. The first positive effects of fertilizer application may be recorded six months to one year after initial application. But the maximal positive effects of fertflizer application can be seen about two years after the application of chemical fertilizers. Theoretically, chemical fertflizers, if properly applied, will not only increase the number of fruit per palm but also enlarge the size of the fruits.

\section{THE PROBLEM}

One of the most important questions related to the application of chemical fertilizers for coconut palms in Indonesia is: Which is the most appropriate chemical fertilizers for the coconuts? If this is known, the next question is: What is the appropriate dosage of the fertilizers?

The answers to these questions are not easily obtained. This is because the conditions of coconut palms in Indonesia vary from one location to another. The variations are not only due to differences in soil type and topography but also to climatic and crop variety differences.

In order to solve the problem, exploratory fertilizer trials were conducted by the Coconut Research Institute, Manado, in order to determine the effect of major nutrients, NPKMg, on fruit yield at Pandu (North Sulawesi) and Pangandaran, West Java (Davis, 1983). The experiments were

\footnotetext{
${ }^{1}$ Dr. S. Asnawi and Dr. S.N. Darwis are Agricultural Economist and Head, respectively, Coconut Research Institute, Manado, Indonesia.
} 
started in 1978 and will be concluded at the end of 1985. The difference between the two locations is not only in soil conditions but also in the age of the coconut palms. Further fertilizer trials will be conducted by the institute in more locations covering different soil and climatic conditions.

\section{THE EXPERIMENTS}

The design of the fertilizer experiments is a Randomized Block Design conducted on tall variety coconuts, 55 years old (Pandu trial) and 30 years old (Pangandaran trial), both the sets of palms being mono-cropped at 9 meters spacing on the square system of planting. The annual dosage of fertilizers are given at two levels and are applied at six monthly intervals (Table 1).

There are 16 treatment combinations $\mathrm{G}$ contol +4 nutrients applied singly and in all combinations), replicated three times which makes the total number of plots 96 . The plot size for Pandu is nine effective and 16 border palms (total of about 2400 palms), for Pangandaran is 16 effective and 20 border palms with (total of about 3,456 palms). The duration of fertilizer application is for five years and growth and yield records are to continue for a further two years (total seven years).

Table 1. The type and dosage of fertilizer applied at Pandu and Pangandaran fertilizer trials.*

\begin{tabular}{|l|c|r|l|}
\hline \multirow{2}{*}{$\begin{array}{c}\text { Fertilizer } \\
\text { treatments }\end{array}$} & \multicolumn{2}{|c|}{ Fertilizer dosage $(\mathrm{gr} /$ palm/year $)$} & \multirow{2}{*}{ Applied as } \\
\cline { 2 - 3 } & Lower level & Higher level & \\
\hline $\mathrm{N}$ & 400 & 600 & Urea \\
$\mathrm{P}_{2} \mathrm{O}_{5}$ & 300 & 450 & TSP \\
$\mathrm{K}_{2} \mathrm{O}$ & 800 & 1,200 & KCL \\
$\mathrm{MgO}$ & 200 & 300 & Kieserite \\
\hline
\end{tabular}

* Urea contains $46 \% \mathrm{~N}$, TSP contains $46 \% \mathrm{P}_{2} \mathrm{O}_{5}, \mathrm{KCI}$ contains $60 \% \mathrm{~K}_{2} \mathrm{O}$, and Kieserite contains $26 \% \mathrm{MgO}$.

Source : Davis (1983).

The data collected includes harvest data once every two months (good and barren nuts), as well as the number of female flowers formed. It also covers chemical analysis of leaf tissues from each treatment once every two years, and recording the weights of fruit components twice a year. Furthermore, the number of green leaves in each crown is recorded once a year.

\section{THE OBJECTIVES}

The main objectives of this paper are first, to determine which fertilizers are appropriate for the coconuts of small holders in Pandu and Pangandaran, by reference to the results of the NPKMg fertilizer trials. Second, to identify the fertilizer dosage most appropriate for the achievement of maximum profits. Third, to compare the results of Benefit-cost analysis and Production Function approach when applied to the same data. 


\section{METHODS OF ANALYSIS}

Two methods of analysis were applied in this study. They are Benefit-cost ratio analysis and the Production Function approach.

\section{The Benefit-cost Ratio Analysis ${ }^{2}$}

In this analysis an Incremental Benefit-Cost Ratio (IBCR) was calculated for each fertilizer treatment at the two dosage levels by applying the following equation

$$
\mathrm{IBCR}_{\mathrm{ij}}=\frac{\left(\Delta \mathrm{Y}_{\mathrm{ij}}\right) P_{y}}{\Delta C_{i j}}
$$

where: IBCRij is the Incremental Benefit-Cost Ratio of the $\mathrm{i}^{\text {th }}$ treatment $(\mathrm{i}=$ treatment $1,2 \ldots \ldots . .15$ ) at the $\mathrm{j}^{\text {th }}$ dosage level $0=0,1$, and 1.5 ; where $0=$ control; $1=$ lower level; and $1.5=$ higher level).

? $\mathrm{Y}_{\mathrm{ij}}$ is the additional yield of the $\mathrm{i}^{\text {th }}$ treatment at the $\mathrm{j}^{\text {th }}$ level (in number of nut/palm/year).

? $\mathrm{C}_{\mathrm{ij}}$ is the additional cost of the $\mathrm{i}^{\text {th }}$ treatment at the $\mathrm{j}^{\text {th }}$ level (in Rp/palm/year).

Py is the unit price of the output Y (in Rp/nut).

If $\operatorname{IBCR}_{\mathrm{ij}}>1$, it means that the application of the $\mathrm{i}^{\text {th }}$ fertilizer treatment at the $\mathrm{j}^{\text {th }}$ dosage level will be profitable. On the other hand if $\mathrm{IBCR}_{\mathrm{ij}}=1$, it means that the application of the ith treatment at the $\mathrm{j}^{\text {th }}$ level will not be profitable, and will be a net loss.

It is important to note that the prices of the inputs and of the outputs which were used in this analysis were based on the 1984 farm gate prices.

\section{Production Function Approach ${ }^{3}$}

A Cobb-Douglas production function model was used in this study. The model is :

$$
\mathrm{Y}_{\mathrm{ij}}=\mathrm{a} \mathrm{X}_{\mathrm{ij}}^{\mathrm{b}} \mathrm{u}_{\mathrm{ij}}
$$

or, following conversion to natural logarithms

$$
1 n Y_{i j}=1 n a+b 1 n X_{i j}+1 n u_{i j}
$$

where : $Y_{i j}$ - is the yield of coconut palms from the $i^{\text {th }}$ treatment at the $j^{\text {th }}$ dosage level (the definitions of $i$ and $j$ are the same as those given in Equation 1).

$\mathrm{X}_{\mathrm{ij}}$ - is the amount of fertilizer used in the ith treatment at the jth dosage level.

$\mathrm{u}_{\mathrm{ij}}$ - is the error term for the ith treatment at the $\mathrm{j}^{\text {th }}$ dosage level.

$\mathrm{ln}$ is natural logarithm.

$\mathrm{a}$ and $\mathrm{b}$ are the parameters to be detennined.

\footnotetext{
${ }^{2}$ See Gittinger (1972:47-66)

3 For further details see Heady \& Dillion (1961), Dillon (1968), Henderson \& Quandt (1971), and Koutsoyiannis (1973).
} 
The production functions were estimated by applying the OLS (Ordinary Least Squares) method of estimation to the data of the fertilizer trial results. A Texas instrument (SR-51-II) was used in estimating the production functions. Unfortunately, the standard errors of the parameters could not be calculated with the instrument.

Suppose an estimated production function of the coconut is

$$
Y_{i j}=a X_{i j}^{b}
$$

where : $Y_{i j}$ - is the estimated yield of the coconut from the $i^{\text {th }}$ treatment at the $j^{\text {th }}$ dosage level of fertilizer X.

$\mathrm{X}_{\mathrm{ij}}$ - is the amount of fertilizer $\mathrm{X}$ used of the ith treatment at the $\mathrm{j}^{\text {th }}$ dosage level.

$\mathrm{a}$ and $\mathrm{b}$ are the estimated parameters.

The marginal product of input $\mathrm{X}$ can be calculated from the estimated production function, namely :

$$
\mathrm{MP}_{\mathrm{ij}}=\frac{d \mathrm{Y}_{\mathrm{ij}}}{\mathrm{d} \mathrm{X}_{\mathrm{ij}}}=\mathrm{ab} \mathrm{X}_{\mathrm{ij}}^{\mathrm{b}-1}
$$

where : $\mathrm{MP}_{\mathrm{ij}}$ is the marginal product of input $\mathrm{X}$ from the $\mathrm{i}^{\text {th }}$ treatment at the $\mathrm{j}^{\text {th }}$ dosage level.

$\mathrm{d} \mathrm{Y}_{\mathrm{ij}} / \mathrm{dX}_{\mathrm{ij}}$ is the first derivative of the estimated producn function.

Thus, by using Equation (5) the marginal product of the input at various dosage levels of the input can be calculated.

If the prices of the input and of the output are known, the optimal level of the input to be used in order to attain a maximum profit can be calculated. The profit will be maximal when the marginal product of the input is equal to the ratio between the price of the input and the price of the output. If we suppose the unit price of the output is $\mathrm{P} y$ and the unit price of the input is Px) maximum profit will be reached when :

$$
\mathrm{MP}_{\mathrm{ij}}=\mathrm{P}_{\mathrm{x}} / \mathrm{P}_{\mathrm{y}}
$$

By substituting the value of MPij in Equation (5) to the Equation (6), the following formula is arrived at:

$$
\mathrm{ab} \mathrm{X} \mathrm{X}_{\mathrm{ij}}^{\mathrm{b}-1}=\mathrm{P}_{\mathrm{x}} / \mathrm{P}_{\mathrm{y}}
$$

by supposing $\mathrm{P}_{\mathrm{x}} / \mathrm{P}_{\mathrm{y}}=\mathrm{p}$, then

$$
\begin{aligned}
& a b X_{i j}^{b-1}=p \\
\text { or } \quad & X_{i j}^{b-1}=p / a b
\end{aligned}
$$

When we suppose $\mathrm{p} / \mathrm{ab}=\mathrm{q}$, so that,$\quad X_{\mathrm{ij}}^{\mathrm{b}-1}=\mathrm{q}$ 
or in the form of natural logarithms,

$$
\begin{aligned}
& (\mathrm{b}-1) \ln X_{\mathrm{ij}}=1 \mathrm{n} \mathrm{q} \\
& \text { or } \quad \ln X_{\mathrm{ij}}=(\operatorname{ln~q}) /(\mathrm{b}-1)
\end{aligned}
$$

Since in Equation (8) only the value of $X_{\mathrm{ij}}$. is not known, the value of $X_{\mathrm{ij}}$ can be determined. The value of $X_{\mathrm{ij}}$ is the optimal level of the input $X$ to be used in order to attain the maximum profit. If the optimal level of the input $X$ is supposed to be $X_{0}$, Equation (8) may be represented as:

$$
\ln X_{o}=(\operatorname{lnq}) /(b-1)
$$

By substituting the value of Xo into Equation (4), the optimal yield to attain maximurn profit will be detennined, namely

$$
Y_{\mathrm{o}}=\mathrm{a} \mathrm{X}_{\mathrm{o}}^{\mathrm{b}}
$$

where $Y_{\mathrm{o}}$ is the optimal yield of the coconut in order to attain maximurn profit.

The profit of the coconut can be calculated by using the following formula :

$$
K_{i j}=Y_{i j} P_{y}-X_{i j} P_{x}-C_{i j}(11)
$$

Where: $\mathrm{K}_{\mathrm{ij}}$ - is the profit of the ith treatment at the jth dosage level.

$\mathrm{C}_{\mathrm{ij}}$ - is the total fixed cost of the ith treatment at the $\mathrm{i}^{\text {th }}$ dosage level.

$\mathrm{Y}_{\mathrm{ij},} \mathrm{X}_{\mathrm{ij}}, \mathrm{P}_{\mathrm{y}}$ and Py are the same as the above definitions in Equations (4) and (6).

The profit will be maximurn if the yield is optimum. The yield will be optimum if the input used is also optimum. Since Kmq V and $\mathrm{X}_{\mathrm{o}}$ are profit maximum, yield optimum and input optimurn respectively, the fon-nula for the maximum profit can be written as:

$$
\mathrm{K}_{\mathrm{m}}=\mathrm{Y}_{\mathrm{o}} \mathrm{P}_{\mathrm{y}}-\mathrm{X}_{\mathrm{o}} \mathrm{P}_{\mathrm{x}}-\mathrm{C}
$$

By applying Equation (12), the maximum possible profit from a coconut farm using specific chernical fertilizers can be calculated.

\section{THE ANALYSIS OF RESULTS}

\section{Experiment Results}

Data on the yields of the NPKMg fertilizer trials at Pandu (North Sulawesi) and Pangandaran (West Java) were collected from 1979 to 1984 and will continue to be collected until the end lof 1985. In this analysis we only used the 1982 data because other data from the Pangandaran trial were not available. The 1982 data are shown in Table 2 for Pandu and in Table 3 for Pangandaran.

The average yield of the coconut palms was higher in Pandu than in Pangandaran, both for the controls and all fertilizer treatments. This could be related to soil fertility differences between the two locations. 
Table 2. The result of NPKMg fertilizer trials at Pandu (North Sulawesi) based on 1982 data. *)

\begin{tabular}{|l|c|c|c|c|c|c|}
\hline \multirow{2}{*}{$\begin{array}{l}\text { Fertflizer } \\
\text { treatments }\end{array}$} & \multicolumn{5}{|c|}{ Average yields (nuts/palm/year) } \\
\cline { 2 - 7 } & \multicolumn{3}{|c|}{ Lower levels } & \multicolumn{3}{c|}{ Higher levels } \\
\cline { 2 - 7 } & Yield & $\begin{array}{c}\text { Diff.from } \\
\text { control }\end{array}$ & $\begin{array}{c}\mathrm{t} \\
\text { value }\end{array}$ & Yield & $\begin{array}{c}\text { Diff.from } \\
\text { control }\end{array}$ & $\begin{array}{c}\mathrm{t} \\
\text { value }\end{array}$ \\
\hline Control & 58.32 & - & - & 58.32 & - & - \\
$\mathrm{N}$ & 70.30 & 11.98 & 1.54 & 66.70 & 8.38 & 0.77 \\
$\mathrm{P}$ & 64.70 & 6.38 & 1.32 & 68.80 & 10.50 & 1.07 \\
K & 72.22 & 13.90 & $2.81^{\star \star}$ & 71.16 & 18.84 & $2.12^{\star}$ \\
Mg & 59.67 & 1.35 & 0.76 & 70.07 & 11.75 & 1.92 \\
NP & 66.44 & 8.12 & 1.42 & 50.04 & -7.92 & 0.62 \\
NK & 72.89 & 14.57 & $3.38^{\star \star}$ & 71.11 & 12.79 & $2.10^{\star}$ \\
NMg & 61.07 & 2.75 & 0.51 & 52.89 & -5.43 & 1.17 \\
PK & 65.52 & 7.20 & 0.58 & 60.07 & 2.38 & 0.23 \\
PMg & 64.11 & 5.79 & 0.83 & 65.33 & 7.01 & 0.62 \\
KMg & 63.92 & 5.60 & 0.72 & 67.60 & 9.30 & 0.98 \\
NPK & 62.85 & 4.53 & 0.62 & 75.33 & 17.01 & $3.56^{\star \star}$ \\
NPMg & 70.04 & 11.72 & 1.63 & 54.82 & -3.50 & 0.59 \\
NKMg & 66.07 & 7.75 & 1.26 & 71.74 & 13.42 & $2.16^{\star}$ \\
PKMg & 70.96 & 12.64 & 2.09 & 63.96 & 5.64 & 0.67 \\
NPKMg & 73.82 & 15.50 & $3.47^{\star \star}$ & 71.15 & 12.83 & $2.11^{\star}$ \\
\hline
\end{tabular}

*) Lower levels: $\quad \mathrm{N}=400$ gr or 869.6 gr Urea/palm/year $\mathrm{P}=300 \mathrm{gr}$ or $652.2 \mathrm{gr} \mathrm{TSP} / \mathrm{palm} / \mathrm{year}$ $\mathrm{K}=800 \mathrm{gr}$ or $1,333.3 \mathrm{gr} \mathrm{KC} 1 /$ palm/year $\mathrm{Mg}=200 \mathrm{gr}$ or $769.2 \mathrm{gr}$ Kieserite/palm/year

Higher levels: $\mathrm{N}=600$ gr or 1,304.0 gr Urea/palm/year

$\mathrm{P}=450 \mathrm{gr}$ or $978.3 \mathrm{gr} \mathrm{TSP} / \mathrm{palm} / \mathrm{year}$

$\mathrm{K}=1,200 \mathrm{gr}$ or $2,000.0 \mathrm{gr} \mathrm{KC1} / \mathrm{palm} /$ year

$\mathrm{Mg}=300 \mathrm{gr}$ or 1,153.8 gr Kieserite/palm/year

* significant at 5.0 per cent level

** significant at 1.0 per cent level.

Source : Coconut Research Institute, Manado. 
Table 3. The result of NPKMg fertflizer trials at Pangandaran (West Java) based on 1982 data. *)

\begin{tabular}{|l|c|c|c|c|c|c|}
\hline \multirow{2}{*}{$\begin{array}{l}\text { Fertflizer } \\
\text { treatments }\end{array}$} & \multicolumn{5}{|c|}{ Average yields (nuts/palm/year) } \\
\cline { 2 - 7 } & \multicolumn{3}{|c|}{ Lower levels } & \multicolumn{3}{c|}{ Higher levels } \\
\cline { 2 - 7 } & Yield & $\begin{array}{c}\text { Diff.from } \\
\text { control }\end{array}$ & $\begin{array}{c}\mathrm{t} \\
\text { value }\end{array}$ & Yield & $\begin{array}{c}\text { Diff.from } \\
\text { control }\end{array}$ & $\begin{array}{c}\mathrm{t} \\
\text { value }\end{array}$ \\
\hline Control & 35.49 & - & - & 35.49 & - & - \\
N & 50.98 & 15.49 & 0.58 & 47.94 & 12.45 & 0.41 \\
P & 30.56 & -4.93 & 0.21 & 33.86 & -1.63 & 0.07 \\
K & 43.69 & 8.20 & 0.36 & 51.23 & 15.74 & 0.63 \\
Mg & 32.15 & -3.34 & 0.14 & 38.00 & 2.51 & 0.11 \\
NP & 41.31 & 5.82 & 0.27 & 39.29 & 3.80 & 0.17 \\
NK & 57.09 & 21.60 & 0.78 & 68.04 & 32.55 & 1.15 \\
NMg & 36.91 & 1.42 & 0.06 & 30.25 & -5.24 & 0.25 \\
PK & 33.94 & -1.55 & 0.07 & 29.46 & -6.03 & 0.30 \\
PMg & 28.90 & -6.59 & 0.31 & 51.17 & 15.68 & 0.62 \\
KMg & 40.13 & 4.64 & 0.18 & 53.40 & 17.91 & 0.76 \\
NPK & 58.94 & 23.45 & 0.81 & 63.92 & 28.43 & 1.13 \\
NPMg & 32.10 & -3.39 & 0.16 & 30.08 & -5.41 & 0.23 \\
NKMg & 59.23 & 23.74 & 0.83 & 63.33 & 27.84 & 1.12 \\
PKMg & 41.61 & 6.12 & 0.28 & 39.75 & 4.26 & 0.18 \\
NPKMg & 59.19 & 23.70 & 0.84 & 67.19 & 31.70 & 1.02 \\
\hline
\end{tabular}

*) Lower levels (per palm/year) :

$\mathrm{N}=400$ gr or 869.6 gr Urea

$\mathrm{P}=300 \mathrm{gr}$ or $652.2 \mathrm{gr}$ TSP

$\mathrm{K}=800$ gr or $1,333.3$ gr KCI

$\mathrm{Mg}=200 \mathrm{gr}$ or $769.2 \mathrm{gr}$ Kieserite

Higher levels (per palm/year) :

$$
\begin{gathered}
\mathrm{N}=600 \text { gr or } 1,304.0 \text { gr Urea } \\
\mathrm{P}=450 \text { gr or } 978.3 \text { gr TSP } \\
\mathrm{K}=1,200 \text { gr or } 2,000.0 \text { gr KCI } \\
\mathrm{Mg}=300 \text { gr or } 1,153.8 \text { gr Kieserite }
\end{gathered}
$$

Source : Davis (1983: Table 1). 


\section{Results of IBCR Analysis}

Firstly, we analysed the results of the NPKMg fertilizer trials in terms of the Ineremental Benefit-Cost Ratio (IBCR). For this analysis, data on the prices of the inputs (fertilizers) and of the output (the fruit of the coconut palms) are needed. The prices of Urea, TSP, KCI, and Kieserite fertilizers were assumed to be the same in all parts of Indonesia since they were under Government control. The prices of fertilizers were Rp 100/kg for Urea, TSP and KCI fertilizer, and Rp 275/kg for Kieserite. The price of coconut differed from one location to the other. The farmgate price of coconut in Pandu was about Rp 80/nut, while in Pangandaran it was about Rp 150/nut. These prices were used in this study.

By using Equation (1) and the 1982 data (as shown in Table 2 for Pandu and in Table 3 for Pangandaran) and the price data, the IBCR of each fertilizer treatment was calculated. The results of this calculation are recorded in Table 4 for Pandu and in Table 5 for Pangandaran. The results show clearly that according to statistical tests, the most significant results of the NPKMg fertilizer trials at Pandu (see Table 2) were the K, NK, NPK, NKMg, and NPKMg fertilizers; other treatments were not significant at the 5.0 per cent level. At Pangandaran (Table 3) all fertilizer treatment results were not statistically significant from the control at the 5.0 per cent level.

According to Davis (1983) this lack of significance was due to the high variance of the average yields since all the data collected from the field were analysed without adjustment. For example, one palm from NK treatment (which shows the highest yield relative to the control, at the higher dosage level) produced only one fruit in one year, and another palm produced only one spadix and 11 fruits, for the same period. These palms had either contracted diseases or they were genetically inferior.

Therefore in this case the requirement of statistical significance was not a good criterion in determining the appropriate fertilizers for coconut farms. In terms of agronomic criteria, the most appropriate fertilizer is that which gives the highest average yield. In this case the most appropriate fertilizer for Pandu would appear to be NPK fertilizer at the higher level (Table 2), and for Pangandaran would appear to be NK fertilizer at the higher level (Table 3).

Since the objective of coconut fertilizing is not only to increase the yield of the coconut palms but also to attain higher profits, the agronomic criteria may sometimes be misleading. In terms of economic criteria, the most appropriate fertilizer is that which gives the highest profits. In this case for Pandu (Table 4) K fertilizer at the lower level would appear to be the most appropriate because its IBCR (2.57) was the highest among the fertilizer treatments. For Pangandaran (Table 5), NK fertilizer at the higher level would appear to be the most appropriate since its IBCR (7.75) was the highest. Thus, for Pangandaran the agronomic and economic criteria gave the same results, i.e. NK fertilizer at the higher dosage level wag the most appropriate.

Whether we use or not the criterion of profitability, it can be concluded from the IBCR analysis that for Pandu (Table 4) the treatments of N, P, K, and NK were profitable not only at the lower level but also at the higher level of the inputs; the treatments of NP, PK, NPMg, PKMg, and $\mathrm{NPKMg}$ were only profitable at the lower level, while the $\mathrm{Mg}, \mathrm{NPK}$, and $\mathrm{NKMg}$ were, only profitable at the higher level; and the treatments of $\mathrm{NMg}, \mathrm{PMg}$ and $\mathrm{KMg}$ were not profitable at either level. For Pangandaran (Table 5), the treatments of N, K, NP, NK, KMg, NPK, NKMg, and NPKMg fertilizers were profitable at both levels; on the other hand the treatments of $\mathrm{P}, \mathrm{PK}$, and $\mathrm{NPMg}$ fertilizers at both levels would result in financial loss since their IBCR were negatives; the treatment of PMg fertilizer was only profitable at the higher level, while PKMg fertilizer treatment was not profitable at the higher level; the treatments of $\mathrm{Mg}$ and $\mathrm{NMg}$ fertilizers were not profitable for both levels. 
The IBCRs of the profitable treatments at Pangandaran were rather higher than those at Pandu. This could be related to the fact that the price of coconut in Pangandaran was much higher (Rp 150/nut) than that in Pandu (Rp 80/nut) while the prices of fertilizers were the same, and also because the additional yields at Pangandaran were higher than those at Pandu.

Table. 4. Incremental Benefit-Cost Ratio (IBCR) of NPKMg fertilizer trials at Pandu (North Sulawesi) based on 1982 data.

\begin{tabular}{|c|c|c|c|}
\hline $\begin{array}{l}\text { Fertilizer } \\
\text { treatments }\end{array}$ & $\begin{array}{l}\text { Additional yield } \\
\text { (Rp/palm/year)* }\end{array}$ & $\begin{array}{l}\text { Addtional cost } \\
\text { (Rp/palm/year)** }\end{array}$ & IBCR *** \\
\hline $\mathrm{N}$ & $\begin{array}{c}958.40 \\
(670.40)\end{array}$ & $\begin{array}{c}386.96 \\
(430.40)\end{array}$ & $\begin{array}{c}2.48 \\
(1.55)\end{array}$ \\
\hline $\mathrm{p}$ & $\begin{array}{c}510.40 \\
(840.09)\end{array}$ & $\begin{array}{c}365.22 \\
(397.83)\end{array}$ & $\begin{array}{c}1.40 \\
(2.11)\end{array}$ \\
\hline$\underline{\mathrm{K}}$ & $\begin{array}{c}1,112.00 \\
(1,027.20)\end{array}$ & $\begin{array}{c}433.33 \\
(500.00)\end{array}$ & $\frac{2.57}{(2.05)}$ \\
\hline $\mathrm{Mg}$ & $\begin{array}{c}108.00 \\
(940.00)\end{array}$ & $\begin{array}{c}511.53 \\
(617.30)\end{array}$ & $\begin{array}{c}0.21 \\
(\underline{1.52})\end{array}$ \\
\hline NP & $\begin{array}{c}649.60 \\
(-)\end{array}$ & $\begin{array}{c}452.18 \\
(528.23)\end{array}$ & $\begin{array}{c}1.43 \\
(-)\end{array}$ \\
\hline NK & $\begin{array}{c}1,165.60 \\
(1,023.20)\end{array}$ & $\begin{array}{c}520.29 \\
(630.40)\end{array}$ & $\begin{array}{c}2.24 \\
(1.62)\end{array}$ \\
\hline $\mathrm{NMg}$ & $\begin{array}{c}220.00 \\
(-)\end{array}$ & $\begin{array}{c}598.49 \\
(747.70)\end{array}$ & $\begin{array}{c}0.37 \\
(-)\end{array}$ \\
\hline PK & $\begin{array}{c}576.00 \\
(190.40)\end{array}$ & $\begin{array}{c}498.55 \\
(597.83)\end{array}$ & $\begin{array}{l}1.16 \\
(0.32)\end{array}$ \\
\hline Pmg & $\begin{array}{c}463.20 \\
(560.80)\end{array}$ & $\begin{array}{c}576.75 \\
(715.13)\end{array}$ & $\begin{array}{c}0.80 \\
(0.78)\end{array}$ \\
\hline $\mathrm{KMg}$ & $\begin{array}{c}448.00 \\
(744.00)\end{array}$ & $\begin{array}{c}644.86 \\
(817.30)\end{array}$ & $\begin{array}{c}0.69 \\
(0.91)\end{array}$ \\
\hline$\underline{\mathrm{NPK}}$ & $\begin{array}{c}362.40 \\
(\underline{1,360.80})\end{array}$ & $\begin{array}{c}585.51 \\
(728.23)\end{array}$ & $\begin{array}{c}0.62 \\
(1.86)\end{array}$ \\
\hline NPMg & $\begin{array}{c}937.60 \\
(-)\end{array}$ & $\begin{array}{c}663.71 \\
(695.53)\end{array}$ & $\begin{array}{c}1.41 \\
(-)\end{array}$ \\
\hline $\mathrm{NKMg}$ & $\begin{array}{c}620.00 \\
(1,073.60)\end{array}$ & $\begin{array}{c}731.82 \\
(947.73)\end{array}$ & $\begin{array}{c}0.85 \\
(1.13)\end{array}$ \\
\hline PKMg & $\begin{array}{l}1,011.20 \\
(451.20)\end{array}$ & $\begin{array}{c}710.05 \\
(915.08)\end{array}$ & $\begin{array}{c}1.42 \\
(0.49)\end{array}$ \\
\hline NPKMg & $\begin{array}{c}1,240.00 \\
(1,026.40)\end{array}$ & $\begin{array}{c}797.04 \\
(\underline{1,045.56})\end{array}$ & $\begin{array}{c}1.56 \\
(0.98)\end{array}$ \\
\hline
\end{tabular}

*Additional yield (Table 2) multiplied by Rp 80 (unit price, of coconut ftuits).

**Unit price of fertilizer plus Rp 300 (per palm/year) = other costs.

***Additional yield divided by additional cost (per palm/year).

Notes: Figures in brackets refer to the higher level of fertilizer dosage and those without brackets to the lower levels.

Underlined figures $=$ the highest figure. And $-=$ negative figures . 
Table 5. Incremental Benefit-Cost Ratio (IBCR) of NPKMg fertilizer trials at Pangandaran (West Java) based on 1982 data.

\begin{tabular}{|c|c|c|c|}
\hline $\begin{array}{l}\text { Fertilizer } \\
\text { treatments }\end{array}$ & $\begin{array}{l}\text { Additional yield } \\
\text { (Rp/palm/year) }\end{array}$ & $\begin{array}{l}\text { Additional cost } \\
\text { Rp/palm/year)* }\end{array}$ & $\mathrm{IBCR}^{* * *}$ \\
\hline $\mathrm{N}$ & $\begin{array}{c}2,323.50 \\
(1,867.50)\end{array}$ & $\begin{array}{c}386.96 \\
(430.43)\end{array}$ & $\begin{array}{c}6.00 \\
(4.34)\end{array}$ \\
\hline $\mathrm{p}$ & $\begin{array}{l}- \\
(-)\end{array}$ & $\begin{array}{c}365.22 \\
(397.83)\end{array}$ & $\begin{array}{l}- \\
(-)\end{array}$ \\
\hline K & $\begin{array}{c}1,230.00 \\
(2,361.00)\end{array}$ & $\begin{array}{c}433.30 \\
(499.95)\end{array}$ & $\begin{array}{c}2.84 \\
(4.72)\end{array}$ \\
\hline $\mathrm{Mg}$ & $\begin{array}{c}- \\
(376.50)\end{array}$ & $\begin{array}{c}511.53 \\
(617.30)\end{array}$ & $\begin{array}{c}- \\
(0.61)\end{array}$ \\
\hline NP & $\begin{array}{c}873.00 \\
(570.00)\end{array}$ & $\begin{array}{c}452.18 \\
(528.27)\end{array}$ & $\begin{array}{c}1.93 \\
(1.08)\end{array}$ \\
\hline NK & $\begin{array}{c}3,240.00 \\
(4,882.50)\end{array}$ & $\begin{array}{c}520.29 \\
(630.40)\end{array}$ & $\begin{array}{c}6.22 \\
(7.75)\end{array}$ \\
\hline $\mathrm{NMg}$ & $\begin{array}{c}213.00 \\
(-)\end{array}$ & $\begin{array}{c}598.49 \\
(747.70)\end{array}$ & $\begin{array}{l}0.36 \\
(-)\end{array}$ \\
\hline PK & - & $\begin{array}{c}498.55 \\
(597.83)\end{array}$ & $\begin{array}{l}- \\
(-)\end{array}$ \\
\hline Pmg & $(2,3 \overline{52} .00)$ & $\begin{array}{c}576.75 \\
(715.13)\end{array}$ & $\begin{array}{c}- \\
(3.29)\end{array}$ \\
\hline $\mathrm{KMg}$ & $\begin{array}{c}696.00 \\
(2,686.50)\end{array}$ & $\begin{array}{c}644.86 \\
(817.30)\end{array}$ & $\begin{array}{c}1.08 \\
(3.29)\end{array}$ \\
\hline NPK & $\begin{array}{c}3,517.50 \\
(4,264.50)\end{array}$ & $\begin{array}{c}585.51 \\
(728.23)\end{array}$ & $\begin{array}{c}6.01 \\
(5.86)\end{array}$ \\
\hline NPMg & $\begin{array}{l}- \\
(-)\end{array}$ & $\begin{array}{c}663.71 \\
(695.53)\end{array}$ & $\begin{array}{l}- \\
(-)\end{array}$ \\
\hline $\mathrm{NKMg}$ & $\begin{array}{c}3,561.00 \\
(4,176.00)\end{array}$ & $\begin{array}{c}731.82 \\
(947.73)\end{array}$ & $\begin{array}{c}4.87 \\
(4.41)\end{array}$ \\
\hline PKMg & $\begin{array}{c}918.00 \\
(639.00)\end{array}$ & $\begin{array}{c}710.05 \\
(915.08)\end{array}$ & $\begin{array}{c}1.29 \\
(0.69)\end{array}$ \\
\hline NPKMg & $\begin{array}{c}3,555.00 \\
(4,755.00)\end{array}$ & $\begin{array}{c}797.04 \\
(1,045.56)\end{array}$ & $\begin{array}{c}4.46 \\
(4.55)\end{array}$ \\
\hline
\end{tabular}

*Additionai yield (Table 3) multiplied by Rp 150 (unit price of coconut)

**As in Table 4

***As in Table 4

- = negative figures

Notes : See notes in Table 4.

In conclusion, from the econornic point of view, the appropriate fertilizers for smallholder coconut farms at Pandu were N, P, K, and NK fertilizers. At both le-vels, the most appropriate one being $\mathrm{K}$ fertilizer. The appropriate fertilizers for Pangandaran were $\mathrm{N}, \mathrm{K}, \mathrm{NP}, \mathrm{NK}, \mathrm{KMg}, \mathrm{NPK}$, NKMg and NPKMg fertilizers also at both levels, the most appropriate one being NK fertilizers at the higher level. 


\section{Production Function Analysis Results}

Fifteen Cobb-Douglas production functions of the coconuts with fifteen fertilizer treatment variations were estimated for each location of the NPKMg fertilizer trials by using the model in Equation (2) with the data of Tables 2 (for Pandu) and 3 (for Pangandaran). The estimated production functions can be seen in Table 6 for Pandu and in Table 7 for Pangandaran.

The next questionifter estimating the production functions is the question on which of those production functions are reliable enough to be used in the following analysis, and what are the criteria for this?

The fitness of an estimated production function is determined by its coefficient of determination $\left(\mathrm{r}^{2}\right)$. The larger the coefficient the better the production function. Other criteria for the identification of production functions are the sign and the value of their $b$ parameters. If the sign of $\mathrm{b}$ is positive it means that the application of that fertilizer will increase the yield of the coconut. If it is negative it shows that the application of that fertilizer will decrease the yield of the coconut. Thus, ail fertilizer treatments with negative $b$ parameters arc not suitable for coconut and are therefore not recommended for use by coconut farmers. If $\mathrm{a} b$ parameter is not significantly different from zero it means that the application of the fertilizer will n6t significantly increase the yield of the coconut. Since the calculator used in the estimation of the production functions was not able to give the standard errors of the parameters we were not able to test whether the parameters significantly different from zero or not. It is therefore ail production functions with positive $b$ parameters and high enough their $\mathrm{r}^{2} \mathrm{~s}$ will be used for further analysis.

Based on these criteria, the appropriate fertilizers for Pandu (see Table 6) were N, P, K, NK, $\mathrm{PMg}, \mathrm{KMg}, \mathrm{NPK}, \mathrm{NKMg}, \mathrm{PKMg}$, and NPKMg. These results were not the same as those of the IBCR analysis above. It is important to note that $\mathrm{Mg}, \mathrm{PK}$, and NPMg of the parameters we were not able to that whether the parameters, fertilizers were not included as appropriate fertilizers although their $b$ parameters were positive because their $r^{2}$ values were too low i.e. less than 0.50 . We will see later that those fertilizers were not profitable when compared with the control.

According to their productions, the appropriate fertilizers for Pangandaran (Table 7) were N, $\mathrm{K}, \mathrm{NP}, \mathrm{NK}, \mathrm{KMg}, \mathrm{NPK}, \mathrm{NKMg}$, and NPKMg fertilizers. These were not the same NPK, NKMg, $\mathrm{PKMg}$, and NPKMg fertilizers. Thesewere not the same appropriate fertilizer as those determined by the IBCR analysis above. Thus, the PMg fertilizer is not included as an appropriate fertilizer, although its $\mathrm{b}$ parameter is positive because its $\mathrm{r}^{2}$ value is very low $(0.0435)$.

It should be noted that all of those appropriate fertilizers will increase the yields of the coconuts if they are applied at the levels which give marginal products more than zero. If their marginal products are equal to zero, the yields will be maximal. Those fertilizers will be profitable only at certain input levels and the profits will be maximal if they arc applied at their optimal levels (Xo). In Table 6 and Table 7 the value of Xo for each fertilizer treatment with positive b parameters was calculated by applying Equation (9). 
Table 6. Estimated coconut production functions and their properties for Pandu (North Sulawesi) based on 1982 data of NPKMg fertilizer trials.*)

\begin{tabular}{|c|c|c|c|c|c|c|c|}
\hline \multirow[t]{2}{*}{ Inputs } & \multicolumn{2}{|c|}{ Parameter } & \multirow{2}{*}{$r^{2}$} & \multirow{2}{*}{$\mathrm{MP}_{1}$} & \multirow{2}{*}{$\mathrm{MP}_{\mathrm{h}}$} & \multirow{2}{*}{$\mathrm{P}$} & \multirow{2}{*}{ Xo } \\
\hline & $\mathrm{a}$ & $b$ & & & & & \\
\hline $\mathrm{N}$ & 68.11 & 0.0222 & 0.8976 & 1.51 & 1.02 & 1.087 & 1.40 \\
\hline $\mathrm{p}$ & 66.52 & 0.0193 & 0.8964 & 1.28 & 0.86 & 0.815 & 1.59 \\
\hline $\mathrm{K}$ & 71.24 & 0.0289 & 0.9877 & 2.06 & 1.39 & 1.666 & 1.24 \\
\hline $\mathrm{Mg}$ & 64.60 & 0.0154 & 0.4028 & 0.99 & 0.67 & 2.644 & 0.37 \\
\hline NP & 57.47 & -0.0033 & 0.0091 & - & - & 1.902 & - \\
\hline NK & 71.53 & 0.0294 & 0.9775 & 2.10 & 1.42 & 2.753 & 0.76 \\
\hline $\mathrm{NMg}$ & 56.77 & -0.0045 & 0.0631 & -- & & 3.731 & - \\
\hline $\mathrm{PK}$ & 62.53 & 0.0097 & 0.4358 & 0.61 & 0.41 & 2.482 & 0.24 \\
\hline Pmg & 64.54 & 0.0147 & 0.9887 & 0.95 & 0.64 & 3.459 & 0.27 \\
\hline $\mathrm{KMg}$ & 65.55 & 0.0171 & 0.8916 & 1.12 & 0.75 & 4.311 & 0.25 \\
\hline NPK & 68.64 & 0.0243 & 0.5754 & 1.67 & 1.12 & 3.569 & 0.46 \\
\hline NPMg & 61.66 & 0.0070 & 0.0515 & 0.43 & 0.29 & 4.547 & 0.09 \\
\hline $\mathrm{NKMg}$ & 68.59 & 0.0238 & 0.8782 & 1.63 & 1.10 & 5.398 & 0.29 \\
\hline PKMg & 66.99 & 0.0196 & 0.6747 & 1.31 & 0.88 & 5.126 & 0.25 \\
\hline NPKMg & 71.98 & 0.0303 & 0.9624 & 2.18 & 1.47 & 6.213 & 0.34 \\
\hline
\end{tabular}

*) $\mathrm{r}^{2}$ is the coefficient of determination; $\mathrm{MP}_{\mathrm{I}}$ and $\mathrm{MP}_{\mathrm{h}}$ are the marginal products of the inputs at their lower and higher levels, respectively, calculated by using Equation (6); $\mathrm{p}$ is the ratio between input and output prices in:which the prices of the fertilizers are Rp. 100/kg for Urea, TSPInd KCI, and Rp. 275/kg for Kieserite; Xo is the optimal level of the input, calculated by using Equation (7); a and b are estimated parameters of Equation (2); the price of coconut in Pandu is Rp. 80/nut.

It is important to note that $\mathrm{a}$ and $\mathrm{b}$ parameters were estimated by using a Texas Instrument SR-51-II in which the standatd errors of the parameters were not produced so that we cannot test whether the parameters significantly differed from zero or not.

Table 7. Estimated coconut production functions and their properties for Pangandaran (West Java) based on 1982 data of NPKMg fertilizer trials.*)

\begin{tabular}{|c|c|c|c|c|c|c|c|}
\hline \multirow[t]{2}{*}{ Inputs } & \multicolumn{2}{|c|}{ Parameter } & \multirow{2}{*}{$r^{2}$} & \multirow{2}{*}{$\mathrm{MP}_{1}$} & \multirow{2}{*}{$\mathrm{MP}_{\mathrm{h}}$} & \multirow{2}{*}{$\mathrm{P}$} & \multirow{2}{*}{ Xo } \\
\hline & $\mathrm{a}$ & $b$ & & & & & \\
\hline $\mathrm{N}$ & 48.92 & 0.0461 & 0.8976 & 1.51 & 1.02 & 1.087 & 1.40 \\
\hline $\mathrm{p}$ & 32.30 & -0.0132 & 0.8964 & 1.28 & 0.86 & 0.815 & 1.59 \\
\hline$\underline{K}$ & 46.97 & $\underline{0.0453}$ & $\underline{0.9877}$ & $\underline{2.06}$ & $\underline{1.39}$ & $\underline{1.666}$ & $\underline{1.24}$ \\
\hline$\overline{\mathrm{M}} \mathrm{g}$ & $\overline{35.04}$ & $\overline{-0.0011}$ & $\overline{0.4028}$ & 0.99 & $\overline{0.67}$ & $\overline{2.644}$ & $\overline{0.37}$ \\
\hline NP & 40.11 & 0.0033 & 0.0091 & - & - & 1.902 & - \\
\hline NK & 61.45 & 0.0294 & 0.9775 & 2.10 & 1.42 & 2.753 & 0.76 \\
\hline $\mathrm{NMg}$ & 33.39 & -0.0045 & 0.0631 & -- & & 3.731 & - \\
\hline $\mathrm{PK}$ & 31.67 & 0.0097 & 0.4358 & 0.61 & 0.41 & 2.482 & 0.24 \\
\hline Pmg & 38.65 & 0.0147 & 0.9887 & 0.95 & 0.64 & 3.459 & 0.27 \\
\hline $\mathrm{KMg}$ & 46.10 & 0.0171 & 0.8916 & 1.12 & 0.75 & 4.311 & 0.25 \\
\hline NPK & 31.17 & 0.0243 & 0.5754 & 1.67 & 1.12 & 3.569 & 0.46 \\
\hline NPMg & 60.33 & 0.0070 & 0.0515 & 0.43 & 0.29 & 4.547 & 0.09 \\
\hline NKMg & 40.48 & 0.0238 & 0.8782 & 1.63 & 1.10 & 5.398 & 0.29 \\
\hline PKMg & 62.11 & 0.0196 & 0.6747 & 1.31 & 0.88 & 5.126 & 0.25 \\
\hline NPKMg & 71.98 & 0.0303 & 0.9624 & 2.18 & 1.47 & 6.213 & 0.34 \\
\hline
\end{tabular}

*) All notes for Table 6 are applicable to this table with the exception that the price of coconuts for Pangandaran were Rp 150/nut. 
It should be remembered that Xo is the function of the input and output prices (Equation 7) since parameters $a$ and $b$ are constant. Therefore, if the price of the input and/or the price of the output changes, the amount of Xo should be adjusted accordingly. For this, Xo should be calculated using Equation (9) with the new prices of the input and/or of the output to obtain the new optimal level of the input.

The next question is: Which of those appropriate production functions is the most appropriate one. For this, we have to calculate the maximum profits for each appropriate production function by using Equation (12) where Yo is calculated by applying Equation (10). By using the value of Xo in Table 6 for Pandu and in Table 7 for Pangandaran, the maximum profit for each fertilizer treatment with positive b paramaters was calculated. The results can be seen in Table 8 for Pandu and in Table 9 for Pangandaran.

The highest profit for Pandu was given by K fertilizer (Table 8) where by applying 1.2 units of $\mathrm{K}$ (or about 1,653 gr KCI/palm/year) there will get a profit of about Rp 5,270.71/palm/year. The profits of $\mathrm{Mg}, \mathrm{PK}, \mathrm{PMg}, \mathrm{KMg}$, and NPMg fertilizers are not much different from the profit of the control (Table 8). This means that those fertilizers are not appropriate for Pandu smallholdef coconuts in terms of economic point of view. On the other hand, the profits of N, P, K, NK, NPK, $\mathrm{NKMg}, \mathrm{PKMg}$, and NPKMg fertilizers are significantly different from the profit of the control (Table 8). Thus, it may be concluded that all those fertilizers are appropriate for Pandu where the most appropriate one is K fertilizer. As we noted earlier in the IBCR analysis (Table 4), the highest IBCR is for $\mathrm{K}$ fertilizer with the lower level input. Thus, in this case the result of the IBCR analysis for Pandu is the same with thdt of the production function analysis.

Table 8. The calculation of maxitnum profits for each type of fertflizer for Pandu (North Sulawesi) based on estimated optimal input levels.*

\begin{tabular}{|c|c|c|c|c|c|}
\hline Inputs & $\begin{array}{l}\text { Optimal } \\
\text { input } \\
\text { level } \\
\text { (Xo) }\end{array}$ & $\begin{array}{c}\text { Yield/palm } \\
\text { per year } \\
\text { (No.of nut) } \\
\text { (Yo) }\end{array}$ & $\begin{array}{l}\text { Value of } \\
\text { yield } \\
(\mathrm{Rp})\end{array}$ & $\begin{array}{l}\text { Cost of } \\
\text { fertilizing } \\
\quad(\mathrm{Rp})\end{array}$ & $\begin{array}{l}\text { Maximum } \\
\text { profits } \\
(\mathrm{Rp})\end{array}$ \\
\hline $\mathrm{N}$ & 1.40 & 68.6 & 5,488 & 421.74 & $5,066.26$ \\
\hline $\mathrm{p}$ & 1.59 & 67.1 & 5,368 & 403.70 & $4,964.30$ \\
\hline$\underline{\mathrm{K}}$ & $\underline{1.24}$ & $\underline{71.7}$ & $\underline{5,736}$ & $\underline{465.29}$ & $\underline{5,270.71}$ \\
\hline$\overline{\mathrm{Mg}}$ & $\overline{0.37}$ & $\overline{63.6}$ & $\overline{5,088}$ & 378.27 & $\overline{4,709.73}$ \\
\hline NK & 0.76 & 71.0 & 5,680 & 467.40 & $5,212.60$ \\
\hline PK & 0.24 & 61.7 & 4,936 & 347.65 & $4,588.35$ \\
\hline Pmg & 0.27 & 63.3 & 5,064 & 374.72 & $4,689.28$ \\
\hline $\mathrm{KMg}$ & 0.25 & 64.0 & 5,120 & 386.21 & $4,733.79$ \\
\hline NPK & 0.46 & 67.4 & 5,392 & 431.33 & $4,960.67$ \\
\hline NPMg & 0.09 & 60.6 & 4,848 & 332.73 & $4,515.27$ \\
\hline NKMg & 0.29 & 66.6 & 5,328 & 425.25 & $4,902.75$ \\
\hline PKMg & 0.25 & 65.2 & 5,216 & 402.52 & $4,813.48$ \\
\hline NPKMg & 0.34 & 69.7 & 5,576 & 468.99 & $5,107.01$ \\
\hline Control & None & 58.3 & 4664 & None & 4664.00 \\
\hline
\end{tabular}

* The value of the optimal input level per palm per year (Xo) is taken from Table 6. By including Xo into the estimated production function, the optimal yield/palm/year (Yo) can be obtained. By multiplying Yo with its unit price (Rp 80/nut) we get the value of the yield. The cost of fertilizing/palm/year is the multiplication of Xo by its unit price plus Rp 300 (cost of fertilizing/palm/year). The maximum profit is the value of - the yield minus the cost of fertilizing. 
For Pangandaran, the highest profit resulted from NK fertilizer (Table 9). This is also consistent with the result of the IBCR analysis (Table 5). But the level of the input which should be used was much higher in the production function analysis (i.e. 3.751 units) than that in the IBCR analysis (1.5 units). This is because the fertilizer trials were done only at two levels of the input so that the IBCR analysis was only able to analyse not more than the two levels of the input use. The maximum profit of the PMg fertilizer for Pangandaran is less than that of the control (Table 9). This is consistent with the production function results where the $r 2$ of the PMg fertilizer was very low (less than 0. 1) as shown in Table 7. The maximum profits of the NP and PKMg fertilizers are not much different from those of the control (Table 9). This is particularly due to the lower response of the coconuts to thuse fertilizers, as shown by their $\mathrm{b}$ parameters which were much smaller than those of N, K, NK, KMg, NPK, NKMg and NPKMg fertilizers (Table 7). The profits of N, K, NK, $\mathrm{KMg}, \mathrm{NPK}, \mathrm{NKMg}$, and NPKMg fertilizers are much different from the profit of the control (Table 9). Thus, it may be concluded that all those fertilizers are appropriate for Pangandaran where the most appropriate one is NK fertilizer.

As we noted earlier, the optimal levels of the NPKMg fertilizer uses (Xo) were calculated on the basis of the 1984 prices of fertilizers (Rp 100/kg for Urea, TSP and KCI, and Rp 275/kg for Kieserite) and of coconut fruits (Rp 80/nut for Pandu and Rp 150/nut for Pangandaran). Suppose two years ${ }^{4}$ after the application of the fertilizers the price of coconuts drops substantially. In this case the question is: What is the minimal price of coconuts in order to make the application of those fertflizers remain profitable?

Table 9. The calculation of maxiinum profits for each type of fertilizer for Pangandaran (West Java) based on estimated optimal input levels.*

\begin{tabular}{|c|c|c|c|c|c|}
\hline Inputs & $\begin{array}{c}\text { Optimal } \\
\text { input } \\
\text { level } \\
\text { (Xo) }\end{array}$ & $\begin{array}{c}\text { Yield/palm } \\
\text { per year } \\
\text { (No.of nut) } \\
\text { (Yo) }\end{array}$ & $\begin{array}{r}\text { Value of } \\
\text { yield } \\
\text { (Rp) }\end{array}$ & $\begin{array}{c}\text { Cost of } \\
\text { fertilizing } \\
\text { (Rp) }\end{array}$ & $\begin{array}{c}\text { Maximum } \\
\text { profits } \\
(\mathrm{Rp})\end{array}$ \\
\hline $\mathrm{N}$ & 4.15 & 52.2 & 7,830 & 660.87 & $7,169.13$ \\
\hline K & 2.50 & 48.9 & 7,335 & 463.05 & $6,871.95$ \\
\hline NP & 0.69 & 39.9 & 5,833 & 405.00 & $5,428.00$ \\
\hline NK & $\underline{3.73}$ & $\underline{68.3}$ & $\underline{10,245}$ & $\underline{1,121.58}$ & $9,123.42$ \\
\hline$\overline{\mathrm{Pmg}}$ & $\overline{0.30}$ & $\overline{38.0}$ & $\overline{5,700}$ & $\overline{383.02}$ & $\overline{5,316.98}$ \\
\hline $\mathrm{KMg}$ & 0.77 & 45.6 & 6,840 & 565.53 & $6,274.47$ \\
\hline NPK & 2.65 & 65.2 & 9,780 & $1,056.58$ & $8,723.42$ \\
\hline NKMg & 1.68 & 62.8 & 9,420 & $1,125.47$ & $8,294.53$ \\
\hline PKMg & 0.27 & 39.5 & 5,925 & 410.72 & $5,514.28$ \\
\hline NPKMg & 1.58 & 64.5 & 9,675 & $1,085.31$ & $8,589.69$ \\
\hline Control & None & 35.5 & 5,325 & None & $5,325.00$ \\
\hline
\end{tabular}

*Notes from Table 8 are also applicable to this table with one ex ception, i.e. the price of coconuts in Pangandaran is Rp 150/nut.

The application of a fertilizer treatment to coconut palms will not be profitable if the cost of fertilizer (including the costs of labourers for fertilizing) is equal to the value of the additional coconut yield due to the fertilizer treatment. Or, in other words, the minimal price of coconuts in order to make the fertilizer treatment remains profitable can be obtained by dividing the cost of

\footnotetext{
${ }^{4}$ We suppose two years after the application of the fertilizer because, as we have mentioned before, the result of the fertiHzer treatment can be only seen after two years of the fertilizer application.
} 
fertilizer with the additional yield. The results of these calculations can be seen in Table 10 for Pandu and in Table 11 for Pangandaran.

The minimal price of coconuts for $\mathrm{N}$ fertilizer treatment in Pandu is Rp is Rp 40.95/nut (Table 10). nis means that if the price of coconuts is above $\mathrm{Rp} 40.95 /$ nut, the application of $\mathrm{N}$ fertilizer at its optimal level (1.40 units) will be profitable because the value of the additional yield will be higher than the costs of fertilizing. On the other hand, if the price of the coconuts is below the minimal price, the application of the $\mathrm{N}$ fertilizer will get a financial loss because the value of the additional yield will be lower than the costs of fertilizing. If the price of the coconuts is exactly the same as the minimal price, the application of the $\mathrm{N}$ fertilizer will not be profitable and will not get a financial loss either because in this case the value of the additional yield will be equal to the costs of fertilizing.

Based on the above meaning, we may conclude that the higher the minimal price of the coconuts the greater the risk of the respective fertilizer treatment to get a financial loss due to coconut price decline, and vice versa. It is, therefore, a fertilizer treatment with thelowest coconut minimal price is the most appropriate because its risk to get a financial loss is the lowest too when the price of coconuts declined,

Table 1 0. Optimal input levels, additional yields, cost of fertilizing, additional profits, and minitnal price of coconuts for Pandu (North Sulawesi).*

\begin{tabular}{|l|c|c|c|c|c|}
\hline Inputs & $\begin{array}{c}\text { Optimal input } \\
\text { level }\left(\mathbf{X}_{\mathbf{o}}\right)\end{array}$ & $\begin{array}{c}\text { Additional } \\
\text { yields }\left(\mathbf{Y}_{\mathbf{0}}-\mathbf{Y}_{\mathbf{c}}\right)\end{array}$ & $\begin{array}{c}\text { Cost of } \\
\text { fertilizing } \\
(\mathbf{R p})\end{array}$ & $\begin{array}{c}\text { Additional } \\
\text { profit (Rp) }\end{array}$ & $\begin{array}{c}\text { Coconut Price } \\
\text { minimum (Rp) }\end{array}$ \\
\hline $\mathrm{N}$ & 1.40 & 10.3 & 421.74 & 402.26 & 40.95 \\
$\mathrm{P}$ & 1.59 & 8.8 & 403.70 & 300.30 & 45.88 \\
$\mathbf{K}$ & $\mathbf{1 . 2 4}$ & $\mathbf{1 3 . 4}$ & $\mathbf{4 6 5 . 2 9}$ & $\mathbf{6 0 6 . 7 1}$ & $\mathbf{3 4 . 7 2}$ \\
$\mathrm{Mg}$ & 0.37 & 5.3 & 378.27 & 45.73 & 71.73 \\
$\mathrm{NK}$ & 0.76 & 12.7 & 467.40 & 548.60 & 36.80 \\
$\mathrm{PK}$ & 0.24 & 3.4 & 347.65 & -75.65 & 102.25 \\
$\mathrm{PMg}$ & 0.27 & 5.0 & 374.72 & 25.28 & 74.84 \\
$\mathrm{KMg}$ & 0.25 & 5.7 & 386.21 & 69.79 & 67.76 \\
$\mathrm{NPK}$ & 0.46 & 9.1 & 431.33 & 295.67 & 47.40 \\
$\mathrm{NPMg}$ & 0.09 & 2.3 & 332.73 & -148.73 & 144.66 \\
$\mathrm{NKMg}$ & 0.29 & 8.3 & 425.25 & 238.75 & 51.23 \\
$\mathrm{PKMg}$ & 0.25 & 6.9 & 402.52 & 149.48 & 58.34 \\
$\mathrm{NPKMg}$ & 0.34 & 11.4 & 468.99 & 443.01 & 41.14 \\
\hline
\end{tabular}

* The values of $\mathrm{X}_{\mathrm{o}}, \mathrm{Y}_{\mathrm{o}}$ and cost of fertilizing are taken from Table 8. $\mathrm{Y}_{\mathrm{c}}$ is the yield of the control (58.3 ituts for Pandu). Additional profit is additional yield multiplied by $\mathrm{Rp} 80$ (unit price of coconuts). Coconut price minimum is the cost of fertilizing divided by additional yield. At the coconut price minimum, the additional profit is equal to zero. Thus, when the price of coconut is below the minimum, the fertilization of coconuts will not be profitable since the costs of fertilizing are constant, including the prices of fertilizers. 
Table 11. Optimal input levels, additional yields, costs of fertilizing, additional profits, and coconut price minimum for Pangandaran (West Java).*

\begin{tabular}{|l|c|c|c|c|c|}
\hline \multicolumn{1}{|c|}{ Inputs } & $\begin{array}{c}\text { Optimal input } \\
\text { level }\left(\mathbf{X}_{\mathbf{o}}\right)\end{array}$ & $\begin{array}{c}\text { Additional } \\
\text { yields }\left(\mathbf{Y}_{\mathbf{0}}-\mathbf{Y}_{\mathbf{c}}\right)\end{array}$ & $\begin{array}{c}\text { Cost of } \\
\text { fertilizing } \\
(\mathbf{R p})\end{array}$ & $\begin{array}{c}\text { Additional } \\
\text { profit (Rp) }\end{array}$ & $\begin{array}{c}\text { Coconut Price } \\
\text { minimum (Rp) }\end{array}$ \\
\hline $\mathrm{N}$ & 4.15 & 16.7 & 660.87 & 1844 & 39.57 \\
$\mathrm{~K}$ & 2.50 & 13.4 & 463.05 & $1,546.95$ & 34.56 \\
$\mathrm{NP}$ & 0.65 & 4.4 & 405.00 & 103.00 & 92.05 \\
$\mathbf{N K}$ & $\mathbf{3 . 7 3}$ & $\mathbf{3 2 . 8}$ & $\mathbf{1 , 1 2 1 . 5 8}$ & $\mathbf{3 , 7 9 8 . 4 2}$ & $\mathbf{3 4 . 1 9}$ \\
$\mathrm{PMg}$ & 0.30 & 2.5 & 383.02 & -8.02 & 153.21 \\
$\mathrm{KMg}$ & 0.77 & 10.1 & 565.53 & 949.47 & 55.99 \\
$\mathrm{NPK}$ & 2.65 & 29.7 & $1,056.58$ & $3,398.42$ & 35.58 \\
$\mathrm{NKMg}$ & 1.68 & 27.3 & $1,125.47$ & $2,969.53$ & 41.22 \\
$\mathrm{PKMg}$ & 0.27 & 4.0 & 410.72 & 189.28 & 102.68 \\
$\mathrm{NPKMg}$ & 1.58 & 29.0 & $1,085.31$ & $3,264.69$ & 37.42 \\
\hline
\end{tabular}

* All notes for Table 10 are applicable to this table with the exception that the price of coconuts for Pangandaran is Rp. 1,501 nut.

According to the coconut minimal price criterion, the most appropriate fertflizer for Pandu ie $\mathrm{K}$ fertflizer (Table 10) and for Pangandaran is NK fertilizer (Table 11) because their coconut minimal prices are the lowest, i.e. Rp 34.72/nut for Pandu and Rp 34.19/nut for Pangandaran. Those minimal prices interpret that if the price of the coconuts decreases to Rp 35.00/nut in Pandu'and Pangandaran, the application of the K fertilizer in Pandu and of NK fertilizer in Pangandaran'will remain profitable, whfle for the other fertflizer in Pangandaran will remain profitable, while for the other fertilizer will result in financial losses. On the other hand, for example, if the price of coconuts in Pandu increases up to Rp 150.00/nut, all of those fertilizer treatments in Pandu wfll be profitable because their coconut minimal prices are all below Rp 150.00/nut (Table 10). However, the highest additional profit at that coconut price will be given by the $\mathrm{K}$ fertilizer since its coconut minimal price is the lowest.

\section{Analysis Results Comparison}

We have analysed the impact of the NPKMg fertilizer trials in Pandu and Pangandaran with various criteria, namely: Additional yields (AY), Incremental Benefit-Cost Ratio (IBCR), Production Function Properties (PFP), Additional Profits (AP), and Coconut Minimal Price (CMP) criteria. The summary of the impact of the NPKMg fertilizer trials in Pandu and Pangandaran according to those criteria is shown in Table 12.

The criterion of AY is only based on whether the fertilizer trials give additional yields or not. If yes, we put 1 or $\mathrm{h}$ or $1 \mathrm{~h}$ signs appropriate to which of those dosages give additional yields, i.e. 1 for the lower dosage level, $\mathrm{h}$ for the higher dosage level, and $1 \mathrm{~h}$ for both dosage levels. The criterion of IBCR is based on whether the IBCRs of those fertilizers are greater than unity or not. If yes, we put appropriate signs as for the AY criterion. The criterion of PFP is based on valuds of $b$ parameters of those fertilizer trial production functions where if it is positive we put sign of + and if it is not we do not put any sign at all. The criterion of AP is based on whether there is an additional profit or not if we apply those fertilizers at their optimal levels, if yes we put a sign of + and if not we let it blank. The criterion of CMP is based on a condition whether the value of the CMP is below 
or above the 1984 unit price of the coconuts (i.e. Rp 80/nut for Pandu and Rp 150/nut for Pangandaran); if it is below those prices we put sign of + but let it blank if it is equal to or above those price levels.

If we compare the results of the analyses according those criteria the following conclusions could be drawn (see Table 12).

First, the results of the AY analysis are not always consistent with those of the IBCR analysis. For example, in Pandu, PMg and KMg fertilizer treatments give positive AY at the both dosage levels, but in terms of IBCR analysis they are not profitable at either dosage level. Or, in other words, PM'g and KMg fertilizers are appropriate in terms of AY criterion but conversely they are not appropriate when we use IBCR criterion. Thus, in the selection of appropriate fertilizers for a certain location, the IBCR criterion is more reliable than the AY criterion since the objective of the coconut fertilizing is not only to increase yields but also to raise the profits of the coconut farms. The crucial difference between the AY and IBCR analyses is in their approaches. In the AY analysis approach, the prices of the inputs and of the output are not taken into account, while in the IBCR analysis approach are. Thus in the AY analysis the most important criterion of the impact of fertilizers is only based on additional yields, while in the IBCR analysis, the most important criterion is profits, i. e., the value of additional yields relative to the value of fertilizing costs.

Table 12. Appropriate fertilizers for smallholder coconut fanns in Pandu (North Sulawesi) and Pangandaran (West Java) according to various criteria based on 1982 data of the NPKMg fertilizer trial results.*)

\begin{tabular}{|c|c|c|c|c|c|c|c|c|c|c|}
\hline \multirow{2}{*}{$\begin{array}{c}\text { Fertilizer } \\
\text { Treatments }\end{array}$} & \multicolumn{5}{|c|}{ PANDU } & \multicolumn{5}{|c|}{ PANGANDARAN } \\
\hline & $\mathbf{A Y}$ & IBCR & PFP & $\mathbf{A P}$ & CMP & AY & IBCR & PFP & $\mathbf{A P}$ & CMP \\
\hline $\mathrm{N}$ & $1 \mathrm{~h}$ & $1 \mathrm{~h}$ & + & + & + & $1 \mathrm{~h}$ & $1 \mathrm{~h}$ & + & + & + \\
\hline $\mathrm{P}$ & $1 \mathrm{~h}$ & $1 \mathrm{~h}$ & + & + & + & & & & & \\
\hline K & $1 \mathrm{~h}$ & (1) $\mathrm{h}$ & + & + & + & $1 \mathrm{~h}$ & $1 \mathrm{~h}$ & + & + & + \\
\hline $\mathrm{Mg}$ & $1 \mathrm{~h}$ & $\mathrm{~h}$ & + & + & + & $\mathrm{h}$ & & & & \\
\hline NP & 1 & 1 & & & & $1 \mathrm{~h}$ & $1 \mathrm{~h}$ & + & + & + \\
\hline NK & $1 \mathrm{~h}$ & $1 \mathrm{~h}$ & + & + & + & 1 (h) & 1 (h) & + & $(+)$ & $(+)$ \\
\hline $\mathrm{NMg}$ & 1 & & & & & 1 & & & & \\
\hline PK & $1 \mathrm{~h}$ & 1 & + & & & & & & & \\
\hline $\mathrm{PMg}$ & $1 \mathrm{~h}$ & & + & + & + & $\mathrm{h}$ & $\mathrm{h}$ & + & & \\
\hline $\mathrm{KMg}$ & $1 \mathrm{~h}$ & & + & + & + & $1 \mathrm{~h}$ & $1 \mathrm{~h}$ & + & + & + \\
\hline NPK & $1(\mathrm{~h})$ & $\mathrm{h}$ & + & + & + & $1 \mathrm{~h}$ & $1 \mathrm{~h}$ & + & + & + \\
\hline $\mathrm{NPMg}$ & 1 & 1 & & & & & & & & \\
\hline $\mathrm{NKMg}$ & $1 \mathrm{~h}$ & $\mathrm{~h}$ & + & + & + & $1 \mathrm{~h}$ & $1 \mathrm{~h}$ & + & + & + \\
\hline $\mathrm{PKMg}$ & $1 \mathrm{~h}$ & 1 & + & + & + & $1 \mathrm{~h}$ & 1 & + & + & + \\
\hline NPKMg & $1 \mathrm{~h}$ & 1 & $(+)$ & + & + & $1 \mathrm{~h}$ & $1 \mathrm{~h}$ & $(+)$ & + & + \\
\hline
\end{tabular}

* See page 24 for the meaning of AY, IBCR, PFP, AP and CMP.

$1=$ appropriate at the lower level; $h=$ appropriate at the higher level; $1 \mathrm{~h}=$ appropriate at the both levels.

+ sign means appropriate while blank means not appropriate. A sign with a circle means the most appropriate.

Sources: $\quad$ Tables 2 and 3 for AY, Tables 4 and 5 for IBCR, Tables 6 and 7 for PFP, Tables 10 and 11 for AP and CMP. 
Second, the results of AY analysis are not always consistent with those of the PFP approach although both analyses do not include factor of prices of inputs and of the output. For example, the $\mathrm{NMg}$ fertilizer at the lower dosage level is an appropriate fertilizer for Pandu and Pangandaran in terms of AY criterion but it is not in terms of PFP. This is because the AY analysis is only based on the two levels of the input dosage, i.e. the trial closage levels, while in the PFP analysis the result is based on the $b$ parameters of the estimated production function where $b$ is directly as the production elasticity of the input since it is a Cobb-Douglas production function. Thus, the PFP criterion is much better than the AY criterion in detennining the appropriate fertilizers for a certain location where with the PFP criteria we can identify the additional yields of the input at any dosage levels, while with the AY analysis we only can do it at the two dosage trial levels.

Third, the results of the PFP analysis are not always consistent either with those of the AP analysis. For example, PK fertilizer in Pandu and PMg fertilizer in Pangandaran have positive b parameters but they do not give additional profits at their optimal levels. This is also due the fact that in the PFP analysis the prices of the input and of the output are not taken into account, while in the AP analysis are done. Thus, although the $\mathrm{b}$ parameter is positive, the additional profit may be negative at a certain input level since the value of the additional yield is less than the value of the input cost.

Fourth, although the prices of the inputs and of the output are taken into account in IBCR and AP analyses but their results are not always consistent as shown by NP, PK and NPMg fertilizers in Pandu and by PMg fertilizer in Pangandaran (Table 12). This is particularly due to the fact that in the IBCR analysis an IBCR is calculated on the basis of the trial dosage levels of the respective input, while an AP is calculated on the basis of the optimal level of the respective input in order to attain maximal profits. Thus, the crucial difference between IBCR and AP analyse is laid on the level of the input use.

Fifth, the results of the AP analysis is always consistent with those of the CPM analysis in both locations of the NPKMg fertilizer trials. This is because there is a close relationship between AP and CPM or there is a high correlation between thern. The AP will be positive if the CPM is below the 1984 price of the output and conversely the AP will be negative if the CPM is above the price level. It is, however, the CPM analysis is more useful than. the AP analysis since the former is able to give the minimal price of the output to make the application of the input at its optimal level is profitable, while the latter is not.

Sixth, it is quite clear from the above discussions that AP and CPM criteria are the best criteria to be used in the selection of the appropriate fertiliz ' ers for coconut palms since the main objective of coconut fertilization is not only to increase yields of coconut palms but also to raise the profits of smallholder coconut farms.

\section{CONCLUSIONS}

The analysis of the results of the NPKMg fertilizer trials on smallholder coconuts in Pandu (North Sulawesi) and Pangandaran (West Java) leads to the following conclusions:

First, the appropriate fertilizers for smallholder coconut farms in Pandu are N, P, K, Mg, NK, $\mathrm{PMg}, \mathrm{KMg}$, NPK, NKMg, PKMg, and NKPKMg fertilizers at their optimal dosages since the price of coconuts is not less than $\mathrm{Rp}$ 80/nut (Table 10); while those for Pangandaran are N, K, NP, NK, $\mathrm{KMg}, \mathrm{NPK}, \mathrm{NKMg}, \mathrm{PKMg}$, and NPKMg fertilizers also at their optimal dosages and since the price of coconuts is not less than Rp 150/nut (Table 11). Those fertilizers applied at their optimal dosages not only increase the yields of the coconut palms but also raise the net profits for coconut farmers. 
Second, based on the current prices of the inputs and of the output of the coconuts, the most appropriate fertilizers for Pandu and Pangandaran are K and NK fertilizers, respectively. If the prices of coconuts drop from Rp 80/nut (for Pandu) or Rp 150/ nut (for Pangandaran) to Rp 35/nut, the application of $\mathrm{K}$ fertilizer in Pandu and of NK in Pangandaran at their respective optimal dosages will remain profitable, while for the other fertilizers-also at their respective optimal dosages will not be profitable. This is consistent with the fact where the CMP of K fertilizer in Pandu and Pangandaran and of NK fertilizer in Pangandaran are below Rp 35 while of the other fertilizers are above the price of the coconuts (Rp 35/nut) as shown in Table 10 for Pandu and in Table 11 for Pangandaran.

Third, the selection of the most appropriate fertilizer for a certain location may be different when we use different criteria. For example, in ten-ns AY, the most appropriate fertilizer for coconut palms in Pandu is NPK fertilizer at its higher dosage level; but in tenns of the PFP criteria it is the NPKMg fertilizer; while in terms of IBCR, AP and CMP criteria, K fertilizer is the most appropriate one (Table 12). On the other hand, the most appropriate fertilizer for coconut palms in Pangandaran is NK fertilizer according to all criteria with the exception of the PFP criterion where for the PFP criterion the NPKMg fertilizer is the most appropriate one (Table 12).

Fourth, it is quite clear that the AP as well as the CMP analyses, as the follow up of the production function analysis,- are much better than either the IBCR or AY analyses. This is because the AP or the CMP analysis is based on the optimal of input needed to achieve maximurn profit, while the IBCR and AY analyses are not based on that principle. It is important to note that the optimal. level of an. input to achieve maximurn profit can be deten.nined only if the production function of the input and the prices of the input and of the output are known.

\section{RECOMMENDATIONS}

As a result of the outcome of this - study the following recommendations are made :

First, since the existing coconut palms in Inclonesia are located in many regions with different soil and climatic conditions, additional NPKMg fertilizer frials should be carried out in other areas representative of these differences.

Second, the results of the NPKMg fertilizer trials on coconut palms in Pandu and Pangandaran clearly showed that the response of coconut palms to NPKMg fertilizers was positive, not only by increasing yields but also by raising net profits. It is therefore recommended that a prograrn of Inmas Kelapa (Coconut Intensification Program) be started on existing productive coconut palms between 15 and 50 years of age; the prograrn was planned by the Directorate General of estate crops and will cover an area of about 900,000 ha of coconut palms cluring the Reprelita IV (the Fourth Five Year Development Plan) between 1984 and 1989.

Third, the profitability of coconut fertilization is highly dependent on the price of the coconuts as shown in this study. Thus, coconut palms in Pangandaran were much more profitable than. those in Pandu pricipally due to the fact that the price of coconut in Pangandaran was nearly twice that in Pandu. It is therefore recommencled that the Government of Indonesia should have a regulatory policy for coconut prices in order to protect not only consurners but also producers of coconut. For exaniple, a floor price and a ceiling price could be put on coconuts so that coconut farmers would not suffer sudden losses due to fluctuating sale prices. Furthermore consurners would pay a fairer price for coconuts. 


\section{REFERENCES}

Amrizal, R. M. Kumaat, D. Torar and Y. Kindangen (1985). "Tinjauan ekonomi pemupukan NPKMg pada tanaman kelapa: Studi kasus Pandu" (Economic evaluation of NPKMg fertilization on coconut palms: A case study in Pandu, North Sulawesi), a paper presented at the Weekly Seminar of Manado Coconut Research Institute, Monday 7 January.

Asnawi, S. and Darwis S. N. (1984). "Prospek ekonomi tanaman kelapa dan masalahnya di Indonesia" (The economic prospect of coconuts and its problems in Indonesia), Coconut Research Institute, Manado.

Badrun, Mhd. (1984). "Program pengembangan kelapa di Indonesia" (The development program of coconuts in Indonesia), a paper presented in the First National Conference of Coconuts, Medan, Indonesia, 31 July - 2 August.

Balittri Mando (1984a). "Peningkatan Produksi Kelapa dengan Pola Parsial" (To increase coconut production through a partial pattern), Laporan Bulanan Balittri Manado (Monthly Report of Balittri Manado), January.

(1984b). "Efisiensi pemakaian pupuk pada kelapa" (The efficiency of fertilizer use on coconut palms), Laporan Bulanan Balittri Manado (Monthly Report of Balittri Manado), May.

(1984c). "Percobaan pemupukan kelapa di Maluku Utara" (Coconut fertilization trials in North Maluku), Laporan Bulanan Balittri Manado (Monthly Report of Balittri Manado), September.

Darwis, S. N. and Zainal Mahmud (1984). "Teknologi tepat guna dalam pengembangan perkebunan kepala rakyat" (Appropriate technology for the development of smallholder coconut farms), a paper presented in the First National Conference of coconut, Medan, Indonesia, 31 July - 2 August.

Davis, T. A. (1983). "Terminal Report", Research Institute for Industrial Crops, Manado, Indonesia.

Dillon, J. L. (1968). The Analysis of Response in Crop and Livestock Production, Pergamon Press, Oxford.

FAO (1983). "Indonesia: Assistance to Tree Crop Sub-sector Investment Planning TCP/INS/2311 (1), Surnmary Report and Working Papers", Report No. 101/83 TA.INS 41, 11 November.

Gittinger, J. P. (1972). Economic Analysis of Agricultural Projects, The Johns Hopkins University Press, Baltimore and London.

Heady, E. O. and J. L. Dillon (1961). Agricultural Production Function, lowa State University Press, Ames.

Heesch, H. and Kuhlmann (1982). "Market Prospects: Rubber, Palm-oil, Coconut, Cocoa; Consequences for Project Policy", TAD Materialien 11, Hamburg.

Henderson, J. M. and R. E. Quandt (1971). Microeconomic Theory, McGraw-Hill KOGAKUSHA, LTD., Tokyo.

Koutsoyiannis, A. (1977). Theory of Econometrics, The Macmillan Press Limited, London. 